Protocol

\title{
Improved Method for DNA Extraction and Purification from Tetrahymena pyriformis
}

\author{
Ezzouhra El Maaiden ${ }^{1,2}$, Youssef El Kharrassi ${ }^{1}$, Abdel Khalid Essamadi ${ }^{1}$, Khadija Moustaid ${ }^{2}$ \\ and Boubker Nasser ${ }^{1, *}$ \\ 1 Laboratory of Biochemistry and Neurosciences, Department of Biology, University Hassan I, BP 577, \\ 26000 Settat, Morocco; zohra.elmaaiden@gmail.com (E.E.M.); elkharrassiyoussef@gmail.com (Y.E.K.); \\ essamadi2002@yahoo.fr (A.K.E.) \\ 2 Laboratory of Applied Chemistry and Environment, Department of Chemistry, University Hassan I, BP 577, \\ 26000 Settat, Morocco; moustaid_khadija@yahoo.fr \\ * Correspondence: boubker.nasser@uhp.ac.ma; Tel.: +212-067-373-9479
}

Received: 16 March 2019; Accepted: 13 May 2019; Published: 15 May 2019

check for updates

\begin{abstract}
Tetrahymena pyriformis (protozoa) is intensely investigated as a model organism, offering numerous advantages in comprehensive and multidisciplinary studies using morphologic or molecular methods. Since DNA extraction is a vital step of any molecular experiment, here a new mixed surfactant (Sodium dodecyl sulfate (SDS) 20\%/Triton X-100) was adopted for effective DNA extraction from Tetrahymena pyriformis under an easy, fast protocol. The efficiency of this technique was then compared with three widely-used alternative techniques, namely the Chelex 100 matrix, Ammonium pyrrolidine dithiocarbamate (APD) complex and SDS-chloroform methods. DNA extraction was analyzed by pulsed-field gel electrophoresis, spectral measurement, fluorometry (Qubit), restriction enzyme digestion, and polymerase chain reaction. Data analysis revealed that the quantity and quality of the recovered DNA varied depending on the applied DNA extraction method. The new method (SDS 20\%/Triton X-100) was the most efficient for extracting DNA from Tetrahymena pyriformis with high integrity and purity, affordable cost, less time, and suitability for molecular applications.
\end{abstract}

Keywords: Tetrahymena pyriformis; DNA extraction; SDS 20\%/Triton X-100; Chelex ${ }^{\circledR} 100$ matrix; APD complex; SDS-chloroform

\section{Introduction}

The ciliate Tetrahymena pyriformis is a cell model for cellular and molecular biology [1,2]. Like other ciliates, this species has separate germline and soma functions that are embodied by distinct nuclei within a single cell. The germline-like micronucleus (MIC) has its genome held in reserve for sexual reproduction. The soma-like macronucleus (MAC), which possesses a genome processed from that of the MIC, is the center of gene expression, and does not directly contribute DNA to sexual progeny. High-quality isolation and purification of DNA is the first and most undervalued step in molecular biology methods, and depends on the high purity and concentration of extracted DNA [3]. On the other hand, the process should be safe, simple, quick, and low-cost. Finally, the DNA extraction technique chosen should be able to deliver pure DNA samples ready to be used in downstream molecular applications [4]. The basic steps of DNA isolation are (1) the disruption of the cellular structure to create a lysate, (2) the separation of the soluble DNA from cell debris and other insoluble material, and (3) the purification of the DNA of interest from the soluble proteins and other nucleic acids [5]. The elimination of materials by surfactants is one of the most favourable methods of purification, due to their excellent binding ability with a variety of biomolecules and ions [6]. This paper describes a simplified and quick method of DNA extraction from Tetrahymena pyriformis using a new mixed 
surfactant (sodium dodecyl sulfate (SDS) 20\%/Triton X-100). The efficiency of this technique was compared with three widely-used alternative techniques, namely the Chelex 100 matrix, Ammonium pyrrolidine dithiocarbamate (APD) complex and SDS-chloroform methods.

\section{Experimental Design}

Our method consists of the following steps, as shown in Figure 1. The first step was the culture of our strain of Tetrahymena pyriformis (GL, L 1630/1) axenically in the standard medium PPYE (proteose peptone-yeast extract). The culture medium PPYE was removed and the protozoa pellet was submitted to DNA extraction with the SDS/Triton X-100 method. We needed to determine the ratio of SDS/Triton $\mathrm{X}-100$ that provided a high quality and quantity of DNA, so different ratios of SDS/Triton X-100 were tested (0/100, 20/80, 40/60,60/40,80/20, and 100/0); the ratio that provided the highest quality and yield of DNA was compared with three widely-used techniques (Chelex 100 matrix APD complex and SDS-chloroform).

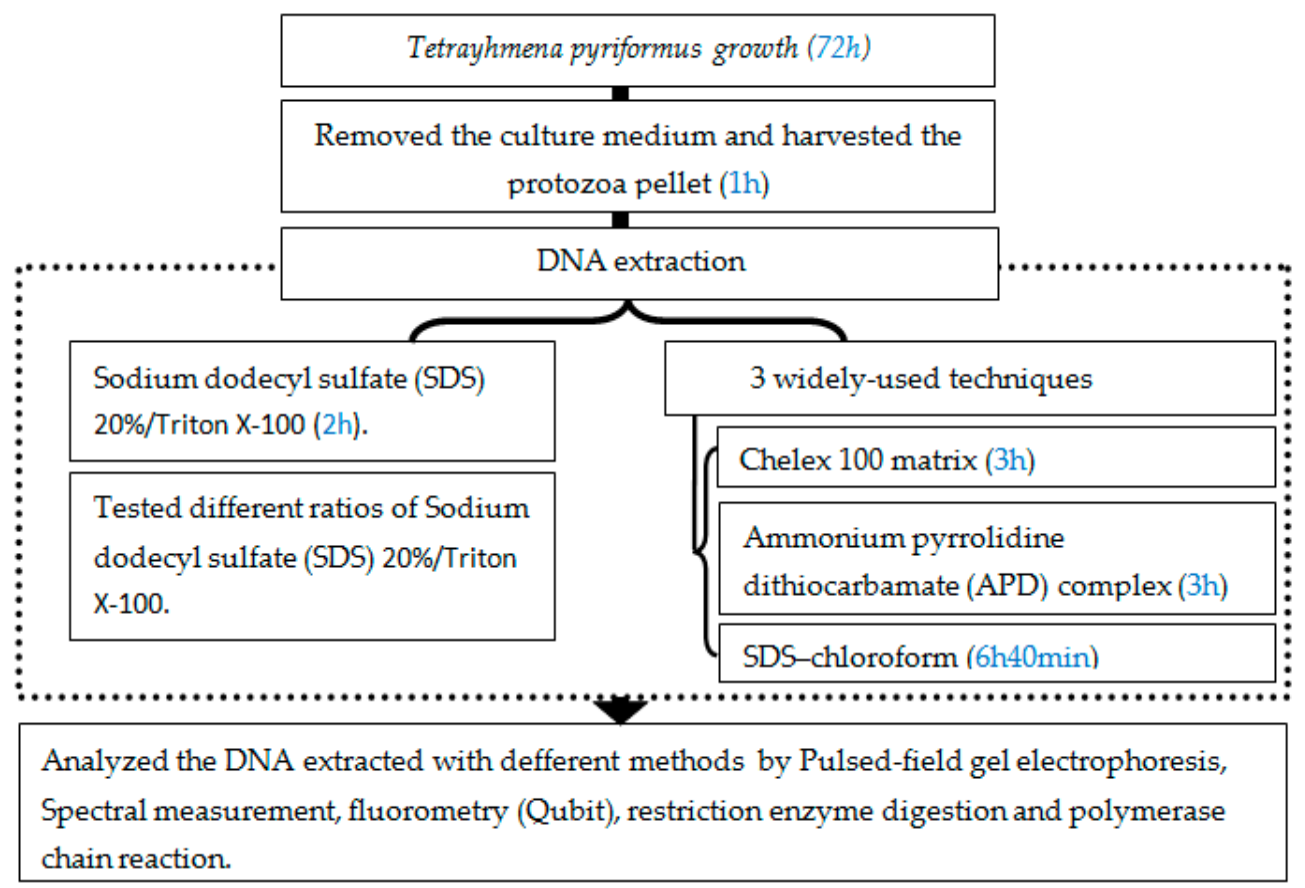

Figure 1. Experimental design for the extraction of DNA with sodium dodecyl sulfate (SDS)/Triton $\mathrm{X}-100$, and the comparison of its quality and quantity with other widely-used methods.

\subsection{Materials}

The following materials were used in the experiment:

- $\quad$ SDS 20\% solution (Thermo Fisher; Waltham, MA, United States; Cat.no.:AM9820);

- Chelex 100 matrix (BIO-RAD; Hercules, CA, United States; Cat.no.:1421253);

- Tris, 1 M, pH 8.0 (Thermo Fisher; Waltham, MA, United States; Cat. no.: AM9855G);

- Ethylene diamine tetra acetic acid (EDTA, Thermo Fisher Scientific; Waltham, MA, United States; Cat. no.: 17892);

- $\quad$ Ethanol 100\% (VWR chemicals, VWR, Radnor, PA, United States; Cat. no.: 64-17-5);

- Proteinase K (Thermo Fisher Scientific; Waltham, MA, United States; Cat. No.: EO0491);

- $\quad$ Agarose molecular grade (Roche, Burgess Hill, United Kingdom; Cat. no.: 11388983001);

- Tris- Ethylenediaminetetraacetic acid (EDTA), (TE, St. Louis, MI, United States; Cat. No.: 99302);

- Restriction endonuclease HindIII (Thermo Scientific, Waltham, MA, United States; Cat.no.:ER0501);

- GeneRuler 1 kb DNA Ladder (Thermo Scientific, Roskilde, Denmark; Cat.no.:SM0311); 
- $\quad$ Primers MT (see Table 1);

- $\quad$ Ethidium Bromide (Thermo Fisher; Wilmington, DE, United States; Cat.no.: 10342020);

- Deoxynucleotide (dTNP) mixture (25 mM) (Takara bio; Shiga, Japan; Cat.no.: 4030);

- Taq Polymerase; (Thermo Fisher; Naerum, Denmark; Cat.no.: 10342020);

- Manganese (II) chloride (Thermo Scientific; Karlsruhe, Allemagne, Cat.no.: 7773-01-5);

\subsection{Equipment}

The following equipment was used in the experiment:

- Microcentrifuge tubes $1.5 \mathrm{~mL}$ (Eppendorf, Hamburg, Germany; Cat. no.: T9661-500EA);

- Pipette-tips, $10 \mu \mathrm{L}, 200 \mu \mathrm{L}, 1 \mathrm{~mL}$ (Axygen, Union City, CA, United States; Cat.no.: 14-222-690, 14-222-812 and14-222-737);

- Shaking heat block (Thermomixer, Eppendorf; Hercules, CA, United States, Cat.no.: 363000233);

- Water bath (JULABO TW9; JULABO, Seelbach, Germany; CAT.no.: 9550323);

- Vortex (Genie 2; Scientific Industries, Bohemia, NY, United States; Cat.no.: SI-T236);

- Laboratory scales (Sartorius, Göttingen, Germany; Cat.no.: ENTRIS623i-1S);

- $\quad$ H meter (HANNA Edge HI2020-02; HANNA, Woonsocket, RI, United States; Cat.no.: HI2020-20);

- Homogenizer (Bullet Blender; Next Advance; Bohemia, NY United States; Cat.no.: 344-0014);

- Autoclave (HIRAYAMA, Saitama, Japan; Cat.no.: 344-0014);

- Microcentrifuge (Eppendorf; Cat. No.: 5424R);

- $\quad-20{ }^{\circ} \mathrm{C}$ freezer (Thermo scientific ${ }^{\mathrm{TM}}$; Goteborg, Sweden; Cat.no.: TSX2320FD);

- $\quad 4{ }^{\circ} \mathrm{C}$ refrigerator (Nor-Lake ${ }^{\mathrm{TM}}$, Goteborg, Sweden; Cat.no.: 22-650-528);

- MilliQ water purification system (Merck Millipore, Burlington, MA, United States; Cat.no.: ZIQ7003T0);

- Gel electrophoresis system (Bio-Rad, Hercules, CA, United States; Cat.no.: 150-0739);

- NanoDrop One Microvolume UV-Vis Spectrophotometers (Thermo Fisher Scientific; Wilmington, DE, United States; Cat.no.: 13-400-519);

- $\quad$ BD Accuri C6 Plus Flow Cytometer (BD Biosciences; Hercules, CA, United States; Cat.no.: 170-3612);

- Qubit fluorometer (Thermo Fisher; Hercules, CA, United States; Cat. no.: Q33226);

- Molecular Imager Gel Doc XR System (BIO-RAD; Hercules, CA, United States; Cat.no.: 1708195EDU);

- Chef-DR II Gel Electrophoresis System (BIO-RAD; Hercules, CA, United States; Cat.no.: 170-3612);

- Polymerase chain reaction (PCR) tubes (Axygen; Hercules, CA, United States; Cat. no.: 14-222-262);

- $\quad$ Rotaphor (Biometra; Gottingen, Germany; Cat.no.: 846-021-101);

- Thermocycler (Super Cycler SC300G, Kyratec, Mansfield, Australia; Cat.no.: SC-200);

\section{Procedure}

\subsection{Strains and Culture Conditions}

- Tetrahymena pyriformis (strain GL, L 1630/1, from The Culture Collection of Algae and Protozoa, The Botany School, Downing Street, Cambridge) was cultured axenically in $5 \mathrm{~mL}$ of the standard medium (PPYE), containing proteose peptone $(1.5 \%, \mathrm{w} / \mathrm{v})$ and yeast extract $(0.25 \%, \mathrm{w} / \mathrm{v})$ (Figure 2$)$.

- The culture was then inoculated with $1 \%(v / v)$ Tetrahymena pyriformis (GL, L 1630/1) preculture in the same medium and incubated at $28{ }^{\circ} \mathrm{C}$ without shaking for $72 \mathrm{~h} \mathrm{[7].}$

- At the end of the incubation time, the culture $\left(6 \times 10^{6} \mathrm{cells} / \mathrm{mL}\right)$ was then harvested at the exponential phase by centrifugation at $5000 \mathrm{rpm}$ for $5 \mathrm{~min}$ at $4^{\circ} \mathrm{C}$.

$\triangle$ CRITICAL STEP To remove the medium completely, decant the medium from the centrifuge tube after centrifugation, invert the centrifuge tube on a paper towel to remove any residual liquid, then tap the tube gently on the paper towel to remove any liquid stuck to the sides of the tube. 
A CRITICAL STEP To get more culture for DNA extraction, repeat the above process by adding more culture to the same centrifuge tube.

- $\quad$ After removing the medium, wash the protozoa cells with $500 \mu \mathrm{L}$ ice cold Tris-EDTA (TE) solution (Tris-EDTA: $100 \mathrm{mM}$ Tris, $10 \mathrm{mM}$ EDTA, $\mathrm{pH} 8.0$ ), resuspend the protozoa pellet by vortexing or slow rounds of pipetting, and centrifuge at $4{ }^{\circ} \mathrm{C}$ for $10 \mathrm{~min}$ at $5000 \mathrm{rpm}$.

- Afterwards, completely remove the supernatant from the tube, add $3.5 \mathrm{~mL}$ of TE solution, and resuspend the protozoa pellet by vortexing or slow rounds of pipetting; then, divide it into aliquots of $1 \mathrm{~mL}$ and submit to DNA extraction, as reported below.

OPTIONAL STEP We follow the proliferation of a cell population with regards to their DNA content using flow cytometry (BD Accuri C6 Plus).

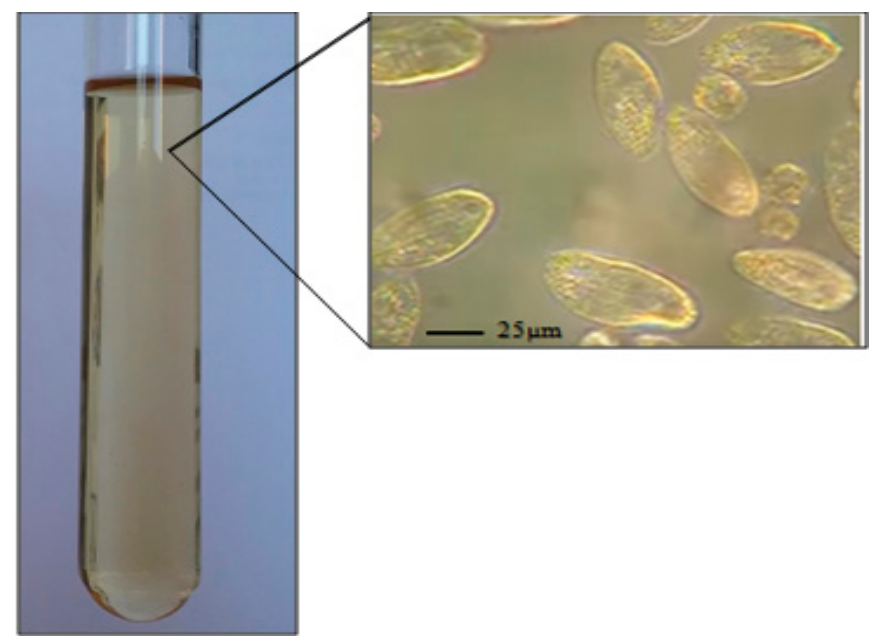

Figure 2. Microscopic image of Tetrahymena pyriformis (GL, L 1630/1) in proteose peptone-yeast extract medium $(\times 100)$.

\subsection{DNA Extraction Methods}

\subsubsection{Sodium Dodecyl Sulphate $20 \%$ /Triton X-100 (the Addition of Mixed Surfactant)}

1. Preparation of the $20 \%$ SDS solution/Triton $\mathrm{X}-100$ complexes (time for fulfillment: $1 \mathrm{~h}$, Figure 3):

- To perform the SDS/Triton X-100 extraction method, the extraction complex 20\% SDS solution/Triton X-100 was prepared beforehand.

OPTIONAL STEP If sodium dodecyl sulfate (20\% solution) is not available, it can be prepared with SDS solid. To prepare $100 \mathrm{~mL}$ of SDS (20\% solution), weigh $20 \mathrm{~g}$ of SDS in a $250 \mathrm{~mL}$ conical flask/beaker. Add $80 \mathrm{~mL}$ deionised/Milli-Q water and mix, heat to $68{ }^{\circ} \mathrm{C}$. Adjust the volume to $100 \mathrm{~mL}$ with deionised/Milli-Q water and mix again.

- $\quad \operatorname{SDS}$ (20\% solution) and Triton X-100 (mass ratios of 0, 20, 40, 60, 80, and $100 \mathrm{wt} \%$ ) were mixed intensively in a vortex mixer, and placed in a water bath at $25{ }^{\circ} \mathrm{C}$ for $45 \mathrm{~min}$.

$\triangle$ CRITICAL STEP If there SDS in the solvent precipitate, re-dissolve it by warming the mix at $60{ }^{\circ} \mathrm{C}$ for $10 \mathrm{~min}$.

- PAUSE STEP The mix can be stored at room temperature for several months. Do not store the SDS (20\% solution) at $4{ }^{\circ} \mathrm{C}$, because SDS will precipitate at temperatures below $15{ }^{\circ} \mathrm{C}$. 


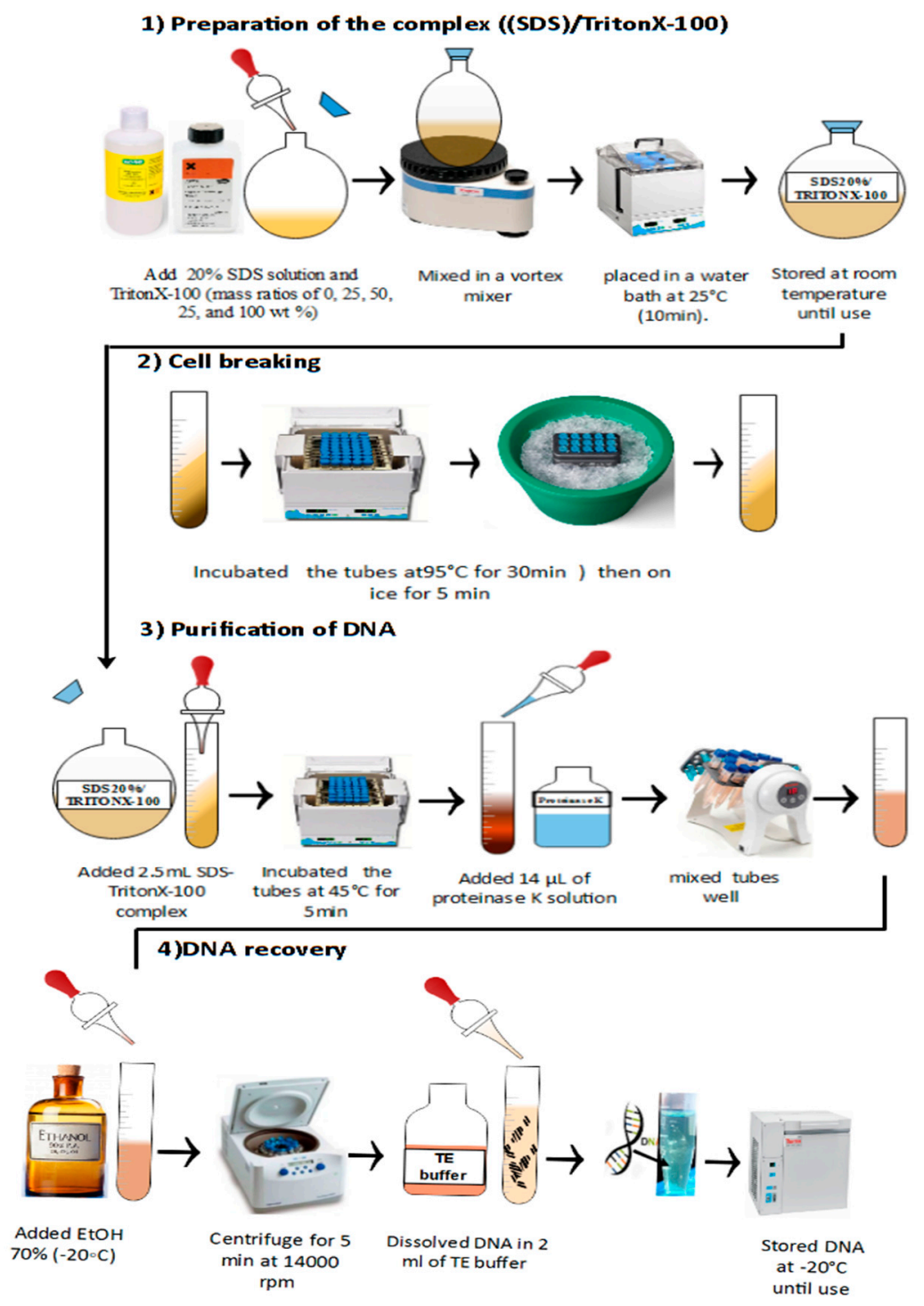

Figure 3. Schematic representation of the SDS $20 \%$ S/Triton X-100 method for the extraction and purification of DNA from Tetrahymena pyriformis.

2. Cell breaking using thermal shock methods (time for fulfillment: 30 min, Figure 3):

- The tubes (1 mL protozoa pellet) were incubated in a water bath at $95{ }^{\circ} \mathrm{C}$ for $20 \mathrm{~min}$ (intermittently vortexing every $5 \mathrm{~min}$ ).

- The tubes were put on ice for $10 \mathrm{~min}$.

3. Purification of DNA (time for fulfillment: $10 \mathrm{~min}$, Figure 3):

- A total of $2.5 \mathrm{~mL}$ of the $\mathrm{SDS} /$ Triton $\mathrm{X}-100 / \mathrm{H}_{2} \mathrm{O}$ complex was added to the tube.

- The tubes were incubated in a water bath at $45^{\circ} \mathrm{C}$ for $5 \mathrm{~min}$.

- After that, $14 \mu \mathrm{l}$ of proteinase $\mathrm{K}$ solution $(20 \mathrm{mg} / \mathrm{mL})$ was added to the suspension, and the tubes were mixed well.

4. DNA recovery (time for fulfillment: $20 \mathrm{~min}$, Figure 3)

- First, $500 \mu \mathrm{L}$ of $70 \%$ ethanol was added to the tube.

- The tube was closed and inverted several times 
- $\quad$ The tubes were centrifuged at $14000 \mathrm{rpm}$ (maximum speed) for $10 \mathrm{~min}$ at $25^{\circ} \mathrm{C}$.

- The supernatant was completely removed.

OPTIONAL STEP to remove the supernatant, one can decant the supernatant after the first centrifugation.

A CRITICAL STEP Take care with this step, as the pellet sometimes does not adhere tightly to the tube and can be lost while removing the supernatant.

- $\quad$ Liquid remains will be stuck on the wall of microcentrifuge tube.

- A second flash spin is sufficient to collect all the liquid at the bottom, which can be then removed by pipetting.

- The pellet was air dried for $5 \mathrm{~min}$.

- The traces of ethanol must then be removed, as they may inhibit some enzyme reactions and dissolve the pellet in $25 \mu \mathrm{L}$ sterile double distilled water or TE ( $\mathrm{pH} 8.0$ ).

$\triangle$ CRITICAL STEP Do not overdry the pellet; overdried pellets are difficult to dissolve.

OPTIONAL STEP To dissolve the pellet, one can vortex the solution gently for a brief period and also incubate it at $37^{\circ} \mathrm{C}$ for $\sim 20 \mathrm{~min}$.

(1 PAUSE STEP The solution can be stored at $4{ }^{\circ} \mathrm{C}$ for a few days or stored at $-20{ }^{\circ} \mathrm{C}$ for years

\subsubsection{DNA Extraction by Chelex 100 Resin APD Complex and SDS-Chloroform}

The extraction of DNA by the Chelex 100 matrix APD complex and SDS-chloroform methods was conducted as described in Table 2, and according to Fenicia et al. [8], Manaffar et al. [9], and Sambrook and Green [10].

\subsection{Cost and Time Consumed}

The cost for each method was estimated based on the price of chemicals, enzymes, and disposable items (including microfuge tubes and pipette tips) consumed for one extraction from a single pellet. The time required to finish one extraction from a single pellet for each method was estimated.

\subsection{Evaluation of the Genomic DNA Quality, Quantity, and Integrity}

A quantitative spectrophotometric assay of DNA was performed using NanoDrop and Qubit. Absorbance was measured at wavelengths of 260 and 280 ( $\mathrm{A}_{260}$ and $\mathrm{A}_{280}$, respectively) nm. The absorbance quotient $\left(\mathrm{A}_{260} / \mathrm{A}_{280}\right)$ provides an estimate of DNA purity. An absorbance quotient value of $1.8<$ ratio $(\mathrm{R})<2.0$ was considered to be good, purified DNA. A ratio of $<1.8$ is indicative of protein contamination, where as a ratio of $>2.0$ indicates RNA contamination. A total of $5 \mu \mathrm{L}$ of DNA was run on a $1 \%$ agarose gel and visualized by UM illumination.

\subsection{Pulsed-Field Gel Electrophoresis (PFGE)}

Pulsed-field gel electrophoresis (PFGE) has been used extensively to prove that both compartments (micronucleus and macronucleus) have been isolated. PFGE was performed in a 1\% agarose gel with 0.52 XTBE buffer (Tris-borate-EDTA) at $8{ }^{\circ} \mathrm{C}$ in a Rotaphor (Biometra). The voltage was set at 200 to $150 \mathrm{~V} / \mathrm{cm}$, and the pulse times ranged from 10 to $100 \mathrm{~s}(\mathrm{log})$. The pulse angle ranged from 120 to 110 (lin) with ramping. The electrophoresis lasted for $24 \mathrm{~h}$. Afterward, the gel was stained with ethidium bromide in the same buffer [11]. 
Table 1. Primer sequences, final concentrations and annealing temperatures for the primers used for measuring the degradation of DNA.

\begin{tabular}{|c|c|c|c|c|c|}
\hline Primer Set (Reference) & Sequence $\left(5^{\prime}-3^{\prime}\right),\left(3^{\prime}-5^{\prime}\right)$ & Denaturing $\left({ }^{\circ} \mathrm{C} ; \mathrm{min}\right)$ & Annealing $\left({ }^{\circ} \mathrm{C} ; \mathrm{min}\right)$ & Elongation $\left({ }^{\circ} \mathrm{C} ; \mathrm{min}\right)$ & $\mathbf{N}^{\circ}$ Cycles \\
\hline $\begin{array}{l}\text { Metallothionein (MT) } \\
\text { primers [12] }\end{array}$ & $\begin{array}{l}\text { CGTGAATAAAATGGATAAGGTTAATAA, } \\
\text { CATTTGCAACATTCACAAGTCTTAC }\end{array}$ & $94 ; 3.5$ & $55 ; 0.4$ & $72 ; 0.3$ & 30 \\
\hline
\end{tabular}

Table 2. Summary of results from comparative study of DNA extraction methods.

\begin{tabular}{|c|c|c|c|c|c|c|c|c|c|c|}
\hline \multirow{2}{*}{$\begin{array}{c}\text { DNA } \\
\text { Extraction } \\
\text { Methods }\end{array}$} & \multicolumn{4}{|c|}{ DNA Extraction Protocol Stage } & \multirow{2}{*}{$\begin{array}{c}\text { Time } \\
\text { Required } \\
\text { (min) }\end{array}$} & \multirow{2}{*}{$\begin{array}{c}\text { Toxic } \\
\text { Compound }\end{array}$} & \multirow{2}{*}{$\begin{array}{c}\text { Cost Per } \\
\text { Sample } \\
\text { (US\$) }\end{array}$} & \multirow[b]{2}{*}{$\mathrm{A} 260 / 2801$} & \multirow{2}{*}{$\begin{array}{c}\text { NanoDrop } \\
\mu \mathrm{g} / \mu \mathrm{L}\end{array}$} & \multirow{2}{*}{$\begin{array}{l}\text { Qubit } \\
\mu \mathrm{g} / \mu \mathrm{L}\end{array}$} \\
\hline & Cell Lysis & $\begin{array}{l}\text { Denaturation of } \\
\text { Nucleoproteins }\end{array}$ & $\begin{array}{c}\text { Removal of } \\
\text { Contaminants }\end{array}$ & $\begin{array}{c}\text { DNA } \\
\text { Precipitation }\end{array}$ & & & & & & \\
\hline SDS-TritonX100 & Thermal shock & Proteinase K & SDS/Triton X-100 & Ethanol & $2 \mathrm{~h}$ & None & $<3$ & 1.81 & 34.75 & 33.77 \\
\hline Chelex100matrix & Heat & Chelex/Proteinase K & Chelex & Isopropanol & $3 \mathrm{~h}$ & Isopropanol & $<3$ & 1.84 & 2.62 & 2.08 \\
\hline APD complex & SDS & Proteinase K & $\begin{array}{c}\text { Ammonium } \\
\text { Pyrrolidine } \\
\text { Dithiocarbamate }\end{array}$ & Ethanol & $3 \mathrm{~h}$ & None & $>3$ & ND & ND & ND \\
\hline SDS-chloroform & SDS & Phenol/Proteinase K & $\begin{array}{l}\text { Phenol-chlorofom } \\
\text { isoamyl alcohol }\end{array}$ & Ethanol & $6 \mathrm{~h} 40 \mathrm{~min}$ & $\begin{array}{c}\text { Phenol, } \\
\text { chloroform }\end{array}$ & $<3$ & 1.08 & 30.87 & 28.79 \\
\hline
\end{tabular}

ND: not detected. ${ }^{1}$ A ratio of approximately 1.8 is accepted as pure DNA. Lower values might be related to the presence of phenol, or other reagent residues used in the DNA extraction. ${ }^{2}$ SDS/Triton X-100: this SDS and Triton X-100 ratio (40/60) provided the best result. 


\subsection{Polymerase Chain Reaction Amplification of the Metallothionein (MT) Gene}

PCR amplification of metallothionein (MT) gene was done in duplicates, using primers targeting the protist Tetrahymena pyriformis (GL, L 1630/1) (Table 1). Reaction mixtures contained $50 \mu \mathrm{L}$ of $1 \times$ buffer KCl-MnCl2 (Fermentas), 1.5 mM MnCl2, 0.5 mM deoxynucleotide solution (dNTPs), 100 pM of each primer set, $1 \mu \mathrm{L}$ Taq Polymerase Recombinant (1 U $\mu \mathrm{L} 174$-1) (Life Technologies, Nærum, Denmark), $350 \mathrm{ng}$ of the extracted DNA, and 2.5 units of Taq DNA polymerase was prepared in a $300 \mu \mathrm{L}$ PCR tube. The PCR conditions are described in Table 1 . Subsequently, $5 \mu \mathrm{L}$ of PCR products were analyzed by electrophoresis on 1\% agarose gel in 1XTAE buffer.

\subsection{Restriction Enzyme Digestion Analysis}

The restriction digestion of the PCR products was carried out with the HindIll enzyme. The PCR products were exposed to digestion by the restriction endonuclease, in a total volume of $20 \mu \mathrm{L}$ (10 $\mu \mathrm{L}$ PCR product, $2 \mu \mathrm{L}$ enzyme buffers, $0.2 \mu \mathrm{L}$ enzymes, and $7.8 \mu \mathrm{L}$ distilled water), and placed in the incubator at $37^{\circ} \mathrm{C}$ for $8 \mathrm{~h}$. The digested products were analyzed on $2 \%$ agarose gel. The restriction products were analyzed by electrophoresis (Bio-Rad) on a $1 \%$ agarose gel, and the molecular weight of restricted fragments was analyzed by gel documentation systems (G-Box; Syngene) after ethidium bromide (Himedia) staining [12].

\section{Expected Results}

DNA was extracted from Tetrahymena pyriformis (GL, L 1630/1) using the supplementation of the mixed surfactant (SDS/Triton X-100) with different ratios (0\%, 20\%, 40\%, 60\%, 80\%, 100\%). The purity and yield of genomic DNA samples were estimated with NanoDrop for the purpose of evaluating parameters like quality and quantity (Figure 4a). The DNA yields were consistently approximately $34 \mu \mathrm{g} / \mu \mathrm{L}$ for all tested samples and replicates. In addition, the DNA was accepted as pure, since the A260/280 ratio was 1.8. Using this measurement method, the A260/280 ratio varied from 1.06-1.80. There was a linear correlation between the starting SDS/Triton X-100 ratio and the purity of the extracted DNA. Based on our results, we observed that the optimal SDS/Triton X-100 ratio for the successful extraction of DNA was $40 \%$ SDS/60\% Triton X-100 (A260/A280 = 1.81).

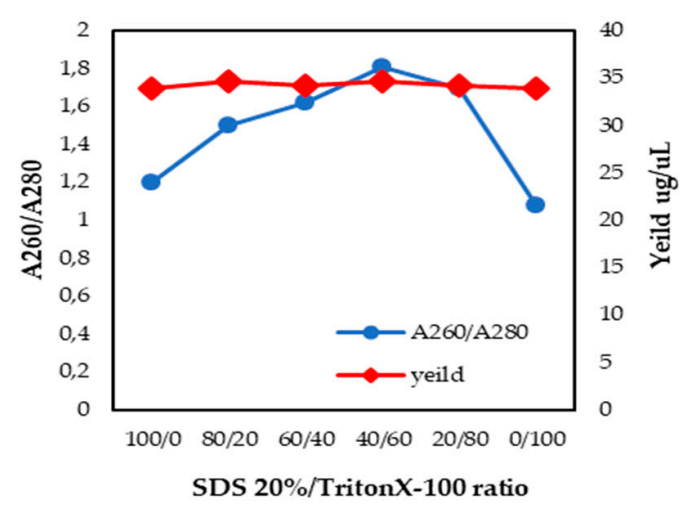

(a)

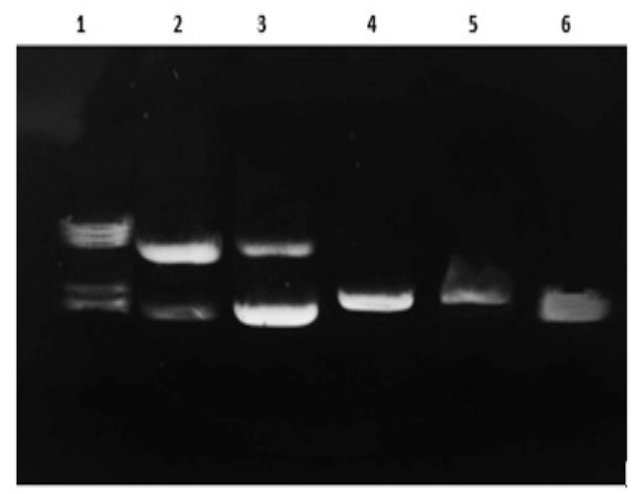

(b)

Figure 4. DNA was extracted and purified from Tetrahymena pyriformis (GL, L 1630/1) using the SDS 20\%/TritonX-100 method. (a) Overview of DNA quality and quantity (NanoDrop), according to the SDS/Triton X-100 ratio-a description of what is contained in the second panel. (b) Electrophoretic analysis of Tetrahymena pyriformis DNA, isolated using various SDS/Triton X-100 ratios. Each lane indicates a different sample (Lane 1: 100/0; Lane 2: 80/20; Lane 3: 60/40; Lane 4: 40/60; Lane 5: 20/80; Lane 6: 0/100).

The integrity of the extracted DNA was determined by gel electrophoresis. As shown in Figure $4 \mathrm{~b}$, lane 4 (40\% SDS/60\% Triton X-100) appeared to correspond to a high-quality extract. Lanes 1, 2, and 3 
showed more than one band, and lanes 5 and 6 showed a non-pure band. This suggests that the DNA in lane 4 was neither contaminated with RNA nor degraded, compared to the DNA in the other lanes; this confirmed the results found with NanoDrop (A260/A280 =1.81).

The efficiency of our SDS/Triton X-100 ratio was then compared with three widely-used alternative techniques, namely the Chelex 100 matrix APD complex and SDS-chloroform methods. As shown in Table 2, data analysis revealed that the time required ( $\mathrm{min}$ ), toxic compound, cost estimate per sample (in USD), and quality and quantity of the recovered DNA varied depending on the DNA extraction method. The highest quality of DNA (A260/A280) was obtained by the SDS/Triton X-100 and Chelex 100 matrix methods (1.81 and 1.84, respectively, where a ratio of approximately 1.8 is accepted as pure DNA). In addition, the maximum yield was obtained with the SDS/Triton X-100 method (34.75 and $33.77 \mathrm{ug} / \mathrm{uL}$ for NanoDrop and Qubit, respectively), while no DNA was detected for the APD complex method. The required time for different methods uses for DNA extraction varied from $2 \mathrm{~h}$ up to $6.4 \mathrm{~h}$. The SDS/Triton X-100 method was the fastest compared to other methods used, although no toxic compound was use and the cost estimate per sample < \$3 USD.

Figure 5a shows the DNA results visualized by agarose gel electrophoresis. The extracts from the Chelex 100 matrix (lanes 1 and 2) and SDS/Triton X-100 (lanes 3 and 4) methods generated clean single bands, while the SDS-Chloroform method (lanes 7 and 8) gave a larger range of fragment sizes. Regarding the APD complex method, no positive bands were detected in the gel electrophoresis (lanes 5 and 6).

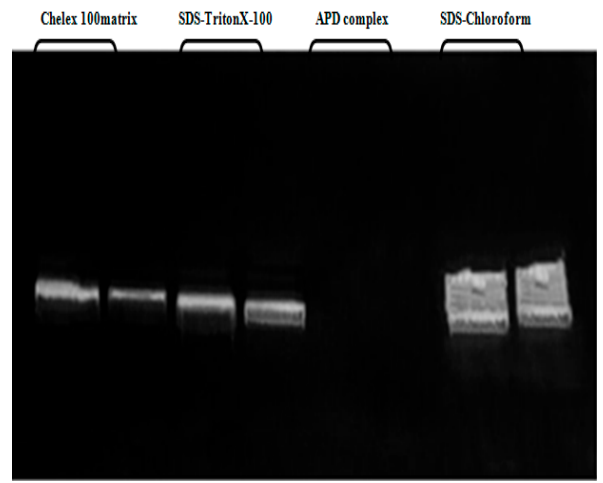

(a)

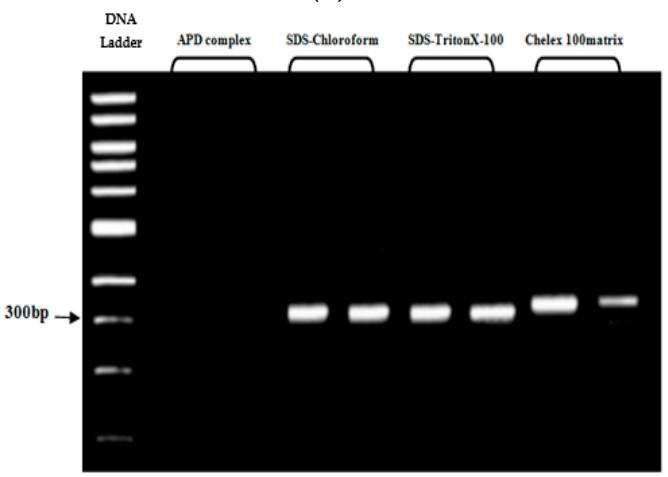

(c)

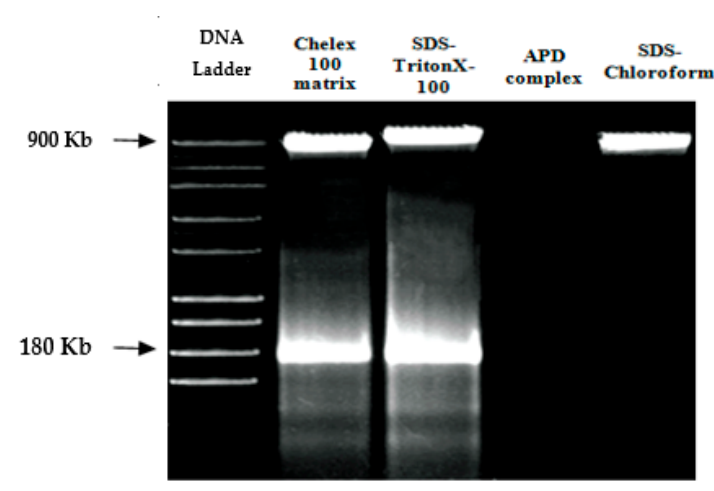

(b)

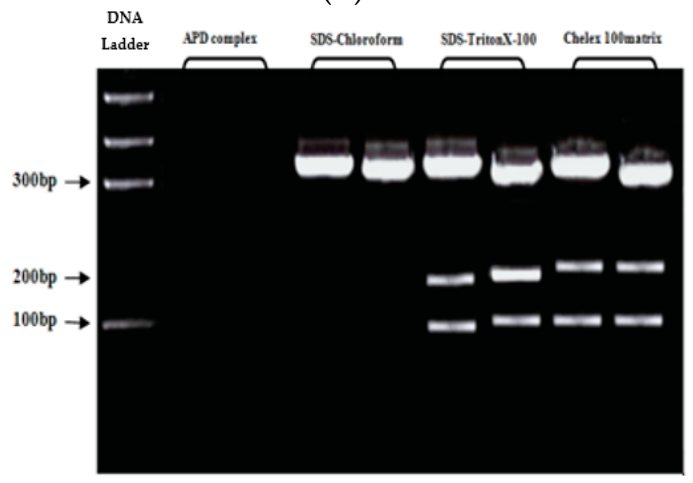

(d)

Figure 5. Electrophoretic analysis (a), pulsed-field gel electrophoresis (PFGE) analysis (b), electrophoresis analysis of the PCR product (c), and electrophoresis analysis of the polymerase chain reaction (PCR) product after digestion with HindIll restriction enzyme (d) of DNA extracted from Tetrahymena pyriformis using various extraction methods.

To prove that both compartments (micronucleus and macronucleus) have been isolated, the DNA extracts from all methods were further subjected to pulsed-field gel electrophoresis (PFGE). As shown in Figure 5b, PFGE generated two bands-one for macronuclear DNA, with a size of $180 \mathrm{~kb}$, and very 
prominent band for micronuclear DNA, with a size of $900 \mathrm{kB}$. In a previous study, the macronuclear DNA of Tetrahymena was found to fluctuate between $100 \mathrm{~kb}$ to $1500 \mathrm{~kb}$, while the micronuclear DNA is much larger [13-15].

In order to confirm their suitability for amplification, DNA extracts were subsequently subjected to PCR analysis for metallothionein (MT) gene-specific primers. Figure $5 \mathrm{c}$ shows the results of PCR amplification of DNA isolated from Tetrahymena pyriformis ( $G L, L$ 1630/1) using different extraction methods. All extracts had positive amplification of the metallothionein gene ( $310 \mathrm{bp})$, except for the DNA extracted by the APD complex method (Lanes 1-2).

The restriction digestion of the PCR products was carried out. As it is seen in Figure 5d, digestion of a $310 \mathrm{bp}$ fragment of metallothionein (MT) gene by HindIll restriction endonuclease generated tree clear bands $(310,220,104 \mathrm{bp})$ for the Chelex 100 matrix and SDS/Triton X-100 methods and one band (310 bp) for the SDS-Chloroform method, while no band was observed for the APD complex method.

\section{Conclusions}

Here, we report a simple method for the extraction and purification of DNA from Tetrahymena pyriformis. The efficiency of this technique was compared to three widely-used alternative techniques, namely the Chelex 100 matrix APD complex and SDS-chloroform methods. We demonstrated that the improved method using SDS/Triton X-100 was the easiest and most cost-effective, and was more suitable for molecular applications, such as the extraction and purification of DNA from Tetrahymena pyriformis compared to the other methods.

Author Contributions: Conceptualization, E.E.M.; validation and formal analysis, all; investigation, B.N. and K.M.; writing—original draft preparation, E.E.M., M.L., and Y.E.K.; writing-review and editing, all; Supervision, E.E.M., B.N., and K.M..; project administration, E.E.M., B.N., and M.K.

Funding: This research received no external funding.

Acknowledgments: Many thanks to Nagib Qarah (Al-Hodeidah University, Department of chemistry) and Aajmi Abderrahman (Ibn Zoher University, Laboratory of engineering and process, Department of chemistry) for the assistance and support in PCR amplification and pulsed-field gel electrophoresis analysis.

Conflicts of Interest: The authors declare no conflict of interest.

\section{References}

1. Darcy, P.; Kelly, J.P.; Leonard, B.E.; Henry, A.B. The effect of lofepramine and other related agents on the motility of Tetrahymena pyriformis. Toxicol. Lett. 2002, 128, 207-214. [CrossRef]

2. Leick, V.; Bog-Hansen, T.C.; Christensen, S.T.; Kaufman, S.J. Concanavalin A Receptors and the Chemosensory Behaviour of Tetrahymena thermophila. Exp. Biol. Online 1996, 1, 1-12. [CrossRef]

3. Yu, S.; Geng, J.; Zhou, P.; Wang, J.; Chen, X.; Hu, J. New hydroxyapatite monolithic column for DNA extraction and its application in the purification of Bacillus subtilis crude lysate. J. Chromatogr. 2008, 1183, 29-37. [CrossRef] [PubMed]

4. Kan, C.W.; Fredlake, C.P.; Doherty, E.A.S.; Barron, A.E. DNA sequencing and genotyping in miniaturized electrophoresis systems. Electrophoresis 2004, 25, 3564-3588. [CrossRef] [PubMed]

5. Barbosa, C.; Nogueira, S.; Gadanho, M.; Chaves, S. DNA extraction: Finding the most suitable method. In Molecular Microbial Diagnostic Methods; Academic Press: Amesterdam, The Netherlands, 2016; pp. 135-154.

6. Fenicia, L.; Anniballi, F.; De Medici, D.; Delibato, E.; Aureli, P. SYBR Green real-time PCR method to detect Clostridium botulinum type A. Appl. Environ. Microbiol. 2007, 73, 2891-2896. [CrossRef] [PubMed]

7. Pousada, R.C.; Cyrne, M.L.; Hayes, D. Characterization of Preribosomal Ribonucleoprotein Particles from Tetrahymena pyriformis. Eur. J. Biochem. 1979, 102, 389-397. [CrossRef]

8. Walsh, P.S.; Metzger, D.A.; Higuchi, R. Chelex 100 as a Medium for Simple Extraction of DNA for PCR-Based Typing from Forensic Material. BioTechniques 2013, 54, 506-513. [CrossRef] [PubMed]

9. Manaffar, R.; Maleki, R.; Zare, S.; Agh, N.; Soltanian, S.; Sehatnia, B.; Sorgeloos, P.; Bossier, P.; Van, G. A New Method for Rapid DNA Extraction from Artemia (Branchiopoda, Crustacea). Int. J. Bioeng. Life Sci. 2010, 6, 123-127. 
10. Green, M.R.; Sambrook, J. Molecular cloning. In A Laboratory Manual, 4th ed.; Cold Spring Harbor Laboratory Press: Cold Spring Harbor, NY, USA, 2012.

11. Carle, G.F.; Frank, F.; Olson, M.V. Electrophoretic separations of large DNA molecule by periodic inversion of electric field. Science 1986, 232, 65-68. [CrossRef] [PubMed]

12. Cheung, A.; Pok, L.; Vincent, K.L.L.; King, M.C. Tilapia metallothionein genes: PCR-cloning and gene expression studies. Biochim. Biophys. Acta 2005, 1731, 654-661. [CrossRef] [PubMed]

13. Conover, R.K.; Brunk, C.F. Macronuclear DNA Molecules of Tetrahymena thermophila. Mol. Cell. Biol. 1986, 6, 900-905. [CrossRef] [PubMed]

14. Yao, M.C.; Gorovsky, M.A. Comparison of the DNA sequences of Tetrahymena macro- and micronuclei. Chromosoma 1974, 48, 1-18. [CrossRef] [PubMed]

15. Yao, M.C.; Yao, C.H. Repeated hexanucleotide C-C-C-C-A-A is present near free ends of macronuclear DNA of Tetrahymena. Proc. Natl. Acad. Sci. USA 1981, 78, 7436-7439. [CrossRef] [PubMed]

(C) 2019 by the authors. Licensee MDPI, Basel, Switzerland. This article is an open access article distributed under the terms and conditions of the Creative Commons Attribution (CC BY) license (http://creativecommons.org/licenses/by/4.0/). 